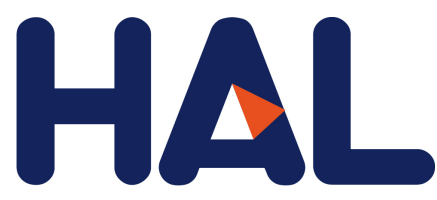

archives-ouvertes

\title{
Biological soil crusts as modern analogs for the Archean continental biosphere: insights from carbon and nitrogen isotopes.
}

\author{
Christophe Thomazo, Estelle Couradeau, Anna Giraldo-Silva, Johanna \\ Marin-Carbonne, Arnaud Brayard, Martin Homann, Pierre Sansjofre, Stefan \\ V. Lalonde, Ferran Garcia-Pichel
}

\section{To cite this version:}

Christophe Thomazo, Estelle Couradeau, Anna Giraldo-Silva, Johanna Marin-Carbonne, Arnaud Brayard, et al.. Biological soil crusts as modern analogs for the Archean continental biosphere: insights from carbon and nitrogen isotopes.. Astrobiology, Mary Ann Liebert, 2020, 20 (7), pp.815-819. 10.1089/ast.2019.2144 . hal-02976854

\section{HAL Id: hal-02976854 \\ https://hal.archives-ouvertes.fr/hal-02976854}

Submitted on 4 Nov 2020

HAL is a multi-disciplinary open access archive for the deposit and dissemination of scientific research documents, whether they are published or not. The documents may come from teaching and research institutions in France or abroad, or from public or private research centers.
L'archive ouverte pluridisciplinaire HAL, est destinée au dépôt et à la diffusion de documents scientifiques de niveau recherche, publiés ou non, émanant des établissements d'enseignement et de recherche français ou étrangers, des laboratoires publics ou privés. 
Accepted version of:

\section{BIOLOGICAL SOIL CRUSTS AS MODERN ANALOGUES FOR THE ARCHEAN CONTINENTAL BIOSPHERE: INSIGHTS FROM CARBON AND NITROGEN ISOTOPES}

Published in: Astrobiology 20, 7, doi.org/10.1089/ast.2019.2144

C. Thomazo ${ }^{1, *}$, E. Couradeau ${ }^{2}$, A. Giraldo-Silva ${ }^{3}$, J. Marin-CARbonne ${ }^{4}$, A. Brayard ${ }^{1}$, M.

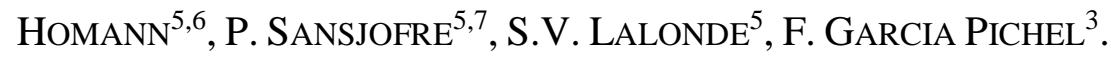

${ }^{1}$ Biogéosciences, UMR6282, CNRS, Université Bourgogne Franche-Comté, 6 Boulevard Gabriel, 21000 Dijon, 0380393578, France (*correspondence: christophe.thomazo@ubourogne.fr)

${ }^{2}$ Joint Genome Institute, Lawrence Berkeley National lab, Walnut Creek, California, USA

${ }^{3}$ Center for Fundamental and Applied Microbiomics, Biodesign Institute, and School of Life Sciences, Arizona State University, Tempe, Arizona, USA

${ }^{4}$ Institut des Sciences de la Terre, Université de Lausanne, Géopolis Mouline, Lausanne, Suisse ${ }^{5}$ European Institute for Marine Studies, CNRS-UMR6538, Laboratoire Géosciences Océan, Technopôle Brest-Iroise, 29280 Plouzané, France ${ }^{6}$ Department of Earth Sciences, University College London, WC1E 6BS London, UK ${ }^{7}$ MNHN, Sorbonne Université, CNRS UMR 7590, IRD, Institut de Minéralogie, de Physique des Matériaux et de Cosmochimie, Paris, France 
Manuscript keywords: isotope biosignature, Early life, Archean, carbon isotope, nitrogen isotope

\begin{abstract}
Stable isotope signatures of elements related to life such as carbon and nitrogen can be powerful biomarkers that provide key information on the biological origin of organic remains and their paleoenvironments. Marked advances have been achieved in the last decade in our understanding of the coupled evolution of biological carbon and nitrogen cycling and the chemical evolution of the early Earth thanks in part to isotopic signatures preserved in fossilized microbial mats and organic matter of marine origin. However, the geologic record of the early continental biosphere, as well as its evolution and biosignatures, are still poorly constrained. Following a recent report of direct fossil evidence of life on land at $3.22 \mathrm{Ga}$, we compare here the carbon and nitrogen isotopic signals of this continental Archean biosphere with biosignatures of cyanobacteria biological soil crusts (cyanoBSCs) colonizing modern arid environments. We report the first extended $\delta^{13} \mathrm{C}$ and $\delta^{15} \mathrm{~N}$ dataset from modern cyanoBSCs and show that these modern communities harbor specific isotopic biosignatures that compare well with continental Archean organic remains. We therefore suggest that cyanoBSCs are likely relevant analogs for the earliest continental ecosystems. As such, they can provide key information on the timing, extent and possibly mechanism of colonization of the early Earth's emergent landmasses.
\end{abstract}

\title{
1. Introduction
}

During the Archean, the absence of an ozone layer resulted in higher short-wavelength irradiance than today despite the fact that the sun was 30\% dimmer (Kasting et al., 1989). Due to 
these extreme environmental conditions, Berkner and Marshall (1965) initially hypothesized that the colonization of Earth's emergent landmass would have been impeded until the formation of an ozone shield. However, later findings showed that sulfur vapor and hydrocarbon smog in the primitive ozone-free atmosphere may have strongly attenuated UV radiation (Kasting et al., 1989), and that the Archean landmasses could have been provided sufficient refugia to early photosynthesizers even under high UV fluxes (Garcia-Pichel, 1998). From a theoretical perspective, a continental ${ }^{*}$ microbial phototrophic biosphere could have therefore existed early, before the Great Oxidation Event (Beraldi-Campesi et al, 2009; Lalonde and Konhauser, 2015), and have colonized emergent land surfaces (Thomazo et al., 2018).

Today, the strictly microbial terrestrial phototrophic biosphere is dominated by biological soils crusts (BSCs). They represent the Earth's largest biofilm, covering $12 \%$ of the continents (Rodriguez-Caballero et al., 2018), typically in areas where plant growth is restricted. While they are composed of a high diversity of microorganisms, they are primarily built by cyanobacteria performing oxygenic photosynthesis (Garcia-Pichel, 2002).

Robust and direct evidence for ancient fossil BSC is found in the 1.2 Ga mid-Proterozoic Apache Supergroup in the Dripping Springs Formation of Arizona (Beraldi-Campesi et al., 2014). Indirect evidence for the presence of an Archean phototrophic biosphere is based on sedimentological observations of paleosols (3.0-3.2 Ga; Retallack et al., 2016) and geochemical arguments suggesting that microorganisms capable of photosynthesis colonized Archean continents prior to the Great Oxidation Event (e.g., Lalonde and Konhauser, 2015; Havig et al., 2019). An early timeline for land colonization, between 3.05 and $2.78 \mathrm{Ga}$, is also suggested by ancestral state

\footnotetext{
${ }^{*}$ Continental referring throughout the text to environments experiencing subaerial exposure and desiccation (e.g. fluvial systems, alluvial fans, dryland and playas) associated with strictly terrestrial biosphere and excluding fully aquatic ecosystems (e.g. lakes, ponds and geothermal springs).
} 
reconstruction and relaxed molecular clock analyses of cyanobacterial diversification (Blank and Sanchez-Baracaldo, 2010; Uyeda et al., 2016; Garcia-Pichel et al., 2019).

Two recent pieces of work made significant advances in the early Earth continental biosphere conundrum. Homann et al. (2018) showed that siliciclastic sediments of the 3.22 Ga Moodies Group (South Africa) preserved fossil microbial mats inhabiting continental habitats (i.e. fluvial with periods of terrestrial subaerial exposure and desiccation) and that their coupled carbon isotope compositions of organic matter and bulk nitrogen isotope compositions are statistically different from strictly marine examples preserved elsewhere in the Moodies Group (e.g, Homann et al., 2015). In addition, Thomazo et al. (2018) carried out a meta-analysis of the biogeochemical cycling of nitrogen by the modern terrestrial phototrophic biosphere and highlighted that this ecosystem would have been capable of importing nitrogen gas from the early atmosphere and exporting ammonium and nitrate to the Archean ocean, presumably through fluvial networks. The present contribution fills the gap between these two recent studies by addressing the $\mathrm{N}$ and $\mathrm{C}$ isotopic signals of modern cyanoBSCs in order to compare their biosignatures with the emerging geochemical continental record of Archean continental life.

\section{Materials and Methods}

A total of 67 cyanoBSCs samples were collected from different desert areas (supplementary Table 1). They were analyzed for their organic carbon and bulk nitrogen isotope compositions at the Biogéosciences laboratory, Université de Bourgogne, Dijon, France (see supplementary information). Their maturity level (successional stage) was inferred based on visual observations according to the sequence provided by Garcia-Pichel (2002). Only cyanobacteria-dominated BSCs were selected for geochemical analyses since moss and lichen biocrusts are not relevant to the early Earth microbial environment. Although cyanobacteria are always largely dominating the biomass 
of early (light) to middle successional stage (dark) BSCs (Chilton et al., 2018), we ran a nonparametric Mann-Whitney $U$ test to determine if lichen-bearing middle stage BSCs $(n=15$, supplementary Table 1) bear different $\mathrm{C}$ and $\mathrm{N}$ isotope distributions. No significant statistical difference was observed in $\mathrm{N}$ isotope compositions between early to middle stage cyanoBSCs and middle stage lichen-bearing BSCs (supplementary Fig. 1). However, for C isotope compositions, measured values are statistically different $(\mathrm{p}<0.01)$ between these two categories. Lichen-bearing BSCs were therefore excluded from our analyses. Early and middle stage cyanoBSCs are statistically identical in their $\mathrm{C}$ and $\mathrm{N}$ isotope compositions ( $\mathrm{p}=0.37$ and 0.39 , respectively; supplementary Fig. 2).

\section{Results}

The isotopic signatures of cyanoBSCs show mean values of $-22.8 \pm 2.3 \%$ and $3.4 \pm 3.5 \%$ ( $1 \sigma$ ) for the $\delta^{13} \mathrm{C}_{\text {org }}$ and $\delta^{15} \mathrm{~N}_{\text {bulk }}$, respectively. With the exception of one study where extreme $\delta^{15} \mathrm{~N}_{\text {bulk }}$ values (in excess of 10\%) were reported in BSCs from Zambia and Botswana (Aranibar et al., 2003), the $\delta^{13} \mathrm{C}_{\text {org }}$ and $\delta^{15} \mathrm{~N}_{\text {bulk }}$ data available in the literature are consistent with our measurements (supplementary Fig. 3). The $\mathrm{C} / \mathrm{N}$ atomic ratio shows a mean value of $9.9 \pm 1.3$, slightly above Redfield. Figure 1 compares observed ranges of $\delta^{13} \mathrm{C}, \delta^{15} \mathrm{~N}$ and $\mathrm{C} / \mathrm{N}$ ratio in our analyses to the main sources of organic matter in continental hydrogeological systems (Finlay and Kendall, 2007), including terrestrial plant detritus and soils (TPDS), macrophytes, benthic algae and cyanobacteria (BAC), and planktonic algae and cyanobacteria (PAC). The isotopic and elementary signatures of cyanoBSCs define a restricted chemical space, partly overlapping the TPDS, BAC and macrophyte data. Based on these isotopic signals, the BSCs and PAC reservoirs are distinguishable (Fig. 1). 
Figure 2 compares the $\delta^{13} \mathrm{C}_{\text {org }}$ and $\delta^{15} \mathrm{~N}_{\text {bulk }}$ signals of the cyanoBSCs measured in this study with the Paleoarchean continental and marine organic remains preserved in the 3.22 Ga old Moodies Group, and to the Paleoarchean marine organic matter reservoir (after Thomazo et al., 2009). The $\delta^{13} C_{\text {org }}$ and $\delta^{15} \mathrm{~N}_{\text {bulk }}$ signatures of the cyanoBSCs and marine Moodies Group are statistically different ( $\mathrm{p}=0.03$ and 0.07 , respectively). However, the isotopic signatures of modern cyanoBSCs are statistically indistinguishable from the continental Moodies Group $(\mathrm{p}=0.25$ and 0.22 for the $\delta^{13} \mathrm{C}_{\text {org }}$ and $\delta^{15} \mathrm{~N}_{\text {bulk, }}$, respectively). Moreover, the Moodies Group continental $\delta^{13} \mathrm{C}_{\text {org }}$ values bear this characteristic signature at a regional scale and in different time units (Figure 2). Paleoarchean marine isotopic signatures are consistent with reported data for marine mats from the Moodies Group, and significantly different than the cyanoBSCs and the continental mats of the Moodies Group.

\section{Discussion}

The isotopic biosignatures of cyanoBSCs are different than the PAC reservoir and exhibit a restricted range when compared to the BAC (Fig. 1). In addition to depositional setting information, these new observations can contribute to interdisciplinary sets of data to help make an integrated biosignature assessment in the geological record. In this way, the Figure 2 thus suggests that cyanoBSCs represent modern analogs of communities that colonized Archean continents. This assumption is consistent with studies suggesting that continental colonization by microbial communities may have triggered oxidative weathering on continental surfaces prior to the Great Oxidation Event (e.g., Lalonde and Konhauser, 2015; Havig et al., 2019). Early life on land would have also enhanced the delivery of nutrients to the oceans such as fixed nitrogen (Thomazo et al., 2018) and would have increased the productivity of Paleoarchean shelfs and coastal margin 
environments (Lyons et al., 2014). Cyanobacterial land-based modern ecosystems may therefore hold keys in understanding how Earth's early terrestrial biogeochemical cycles were established and how they were linked to biogeochemical cycling in the marine environment.

Modern examples of cyanoBSCs from desert sandy soils are thus likely close analogues for microbial communities that thrived in environments available for the development of an early phototrophic biosphere on Archean continents and rocky planetary surfaces (with reduced clays and carbonates), given the aggressive weathering regime postulated for the early Earth that was largely dominated by siliciclastic inputs (Bose et al., 2012). The Moodies Group hosts the oldest known occurrence of quartz-rich sandstones, locally interbedded with conglomerates, which were deposited in alluvial, fluvial, possibly aeolian, deltaic, tidal, and subtidal paleoenvironments (e.g. Homann et al., 2015). However, given their low preservation potential in the rock record and the multibillion-year geological history of these terrestrial ecosystems, their detection primarily relies on geochemical proxies. As such, indirect evidence based on element mobility patterns in several Archean paleosols have been suggested to speak to the presence of an ancient terrestrial biosphere where organic ligands chelated metals during weathering (Rye and Holland, 2000). We suggest that coupled carbon and nitrogen isotopic signatures of Archean organic remains, associated with their sedimentological contexts, can provide a direct way to robustly backtrack deep time phototrophic life on land in deep time.

\section{Conclusions}

Using combined $\mathrm{C}$ and $\mathrm{N}$ isotope biosignatures, we showed here that biological soil crusts represent, among modern microbial ecosystems, a credible analog for one of the oldest archives of continental life on Earth. Moreover, these communities, more widespread at the global scale than hot spring and hydrothermal systems, are thus of prime importance for untangling mechanisms and 
consequences of the early Earth land colonization. They also likely contain key information for understanding the evolution of global biogeochemical cycles toward their modern states.

\section{Acknowledgments}

This work was supported by the Programme National de Planétologie (PNP) of the CNRS INSU, co-funded by CNES. CT and JMC thanks the European Union's Horizon H2020 research and innovation program ERC (STROMATA, grant agreement 759289).

\section{Author Disclosure Statement}

No competing financial interests exist.

\section{References}

Aranibar, J. N., Anderson, I. C., Ringrose, S., and Macko, S. A. (2003) Importance of nitrogen fixation in soil crusts of southern African arid ecosystems: acetylene reduction and stable isotope studies. Journal of Arid Environments 54: 345-358.

Beraldi-Campesi, H., Farmer J., and Garcia-Pichel, F. (2014) Modern terrestrial sedimentary biostructures and their fossil analogs in Mesoproterozoic subaerial deposits. PALAIOS 29: 45-54.

Beraldi-Campesi, H., Hartnett, H., Anbar, A., Gordon, G., and Garcia-Pichel, F. (2009) Effects of biological soil crusts on soil elemental concentrations; implications for biogeochemistry and as traceable biosignatures of ancient life on land. Geobiology 7: 348-359.

Berkner, L. V., and Marshall, L. C. (1965) History of major atmospheric components. Proc. Natl Acad. Sci. USA 53: 1215-1225. 
Blank, C. E., and Sanchez-Baracaldo, P. (2010). Timing of morphological and ecological innovations in the cyanobacteria-a key to understanding the rise in atmospheric oxygen. Geobiology 8: 1-23.

Bose, P. K., Eriksson, P. G., Sarkar, S., Wright, D. T., Samanta, P., Mukhopadhyay, S., Mandal, S., Banerjee, S., and Altermann, W. (2012) Sedimentation patterns during the Precambrian: a unique record? Mar. Pet. Geol. 33: 34-68.

Chilton, A. M., Neilan, B. A., and Eldridge, D. J. (2018) Biocrust morphology is linked to marked differences in microbial community composition. Plant and soil 429: 65-75.

Finlay, J. C., and Kendall, C. (2007) Stable isotope tracing of organic matter sources and food web interactions in watersheds. In Stable isotopes in ecology and environmental science, edited by K. Lajtha and R. Michener, Blackwell, pp 283-333.

Garcia-Pichel, F. (1998) Solar Ultraviolet and the evolutionary history of cyanobacteria. Origins Life Evol. Biosphere 28: 321-347.

Gamper, A., Heubeck, C., Demske, D., and Hoehse, M. (2012) Composition and microfacies of Archean microbial mats (Moodies Group, ca. 3.22 Ga, South Africa). Microbial mats in siliciclastic depositional systems through time. SEPM Special Publication 101: 65-74.

Garcia-Pichel, F. (2002) Desert Environments: Biological Soil Crusts. In Encyclopedia of Environmental Microbiology, edited by G. Bitton, John Wiley, New York, pp 1019-1023.

Garcia-Pichel, F., Lombard, T., Soule, T., Wu, S., Dunaj, S., and Wojciechowski, M. F. (2019) Timing the evolutionary advent of cyanobacteria and the later Great Oxidation Event using gene phylogenies of a sunscreen. mBio 10: e00561-19.

Havig, J. R., and Hamilton, T. L. (2019) Hypolithic photosynthesis in hydrothermal areas and implications for cryptic oxygen oases on Archean continental surfaces. Frontiers in Earth Science $7: 15$ 
Homann, M., Heubeck, C., Airo, A., and Tice, M. M. (2015) Morphological adaptations of 3.22 Ga-old tufted microbial mats to Archean coastal habitats (Moodies Group, Barberton Greenstone Belt, South Africa). Precambr. Res. 266: 47-64.

Homann, M., Sansjofre, P., Van Zuilen, M., Heubeck, C., Gong, J., Killingsworth, B., Foster, I. S., Airo, A., Van Kranendong, M. J., Ader, M., and Lalonde, S. V. (2018) Microbial life and biogeochemical cycling on land 3,220 million years ago. Nature Geoscience 11: 665.

Kasting, J. F., Zahnle, K. J., Pinto, J. P., and Young, A. T. (1989) Sulfur, ultraviolet radiation and the early evolution of life. Orig. Life Evol. Biosph. 19: 95-108.

Lalonde, S. V., and Konhauser, K. O. (2015). Benthic perspective on Earth’s oldest evidence for oxygenic photosynthesis. Proc. Natl Acad. Sci. USA 112: 995-1000.

Lyons, T. W., Reinhard, C. T., and Planavsky, N. J. (2014). The rise of oxygen in Earth’s early ocean and atmosphere. Nature 506: 307.

Retallack, G. J., Krinsley, D. H., Fischer, R., Razink, J. J., and Langworthy, K. A. (2016) Archean coastal-plain paleosols and life on land. Gondwana Research 40: 1-20.

Rodriguez-Caballero, E., Belnap, J., Büdel, B., Crutzen, P. J., Andreae, M. O., Pöschl, U., and Weber, B. (2018) Dryland photoautotrophic soil surface communities endangered by global change. Nature Geoscience 11: 185-189.

Rye, R., and Holland, H. D. (2000) Life associated with a 2.76 Ga ephemeral pond?: evidence from Mount Roe \#2 paleosol. Geology 28: 483-486.

Thomazo, C., Couradeau, E., and Garcia-Pichel, F. (2018) Possible nitrogen fertilization of the early Earth Ocean by microbial continental ecosystems. Nat. Com. 9: 2530.

Thomazo, C., Pinti, D. L., Busigny, V., Ader, M., Hashizume, K., and Philippot, P. (2009). Biological activity and the Earth's surface evolution: insights from carbon, sulfur, nitrogen and iron stable isotopes in the rock record. Comptes Rendus Palevol 8: 665-678. 
Uyeda, J. C., Harmon, L. J., \& Blank, C. E. (2016). A comprehensive study of cyanobacterial morphological and ecological evolutionary dynamics through deep geologic time. PloS one 11: 9.

\section{Figures Captions}

\section{Figure 1}

Typical ranges of $\delta^{13} \mathrm{C}, \delta^{15} \mathrm{~N}$ and $\mathrm{C} / \mathrm{N}$ ratio for the main sources of organic matter in continental hydrogeological systems (modified after Finlay and Kendall, 2007), compared to ranges for cyanobacteria biological soil crusts. TPDS: Terrestrial plant detritus and soils; BAC: benthic algae and cyanobacteria; PAC: planktonic algae and cyanobacteria.

\section{Figure 2}

Comparison of the $\delta^{13} \mathrm{C}_{\text {org }}$ and $\delta^{15} \mathrm{~N}_{\text {bulk }}$ signals of modern analog cyanobacteria biological soil crusts with the Paleoarchean continental and marine organic remains of the Moodies Group (data from unit B of the Dycedale Syncline; Homann et al., 2018 and MdQ1 unit of the Saddleback Syncline; Gamper et al., 2012) and with the Paleoarchean organic matter oceanic reservoir (after Thomazo et al., 2009). 


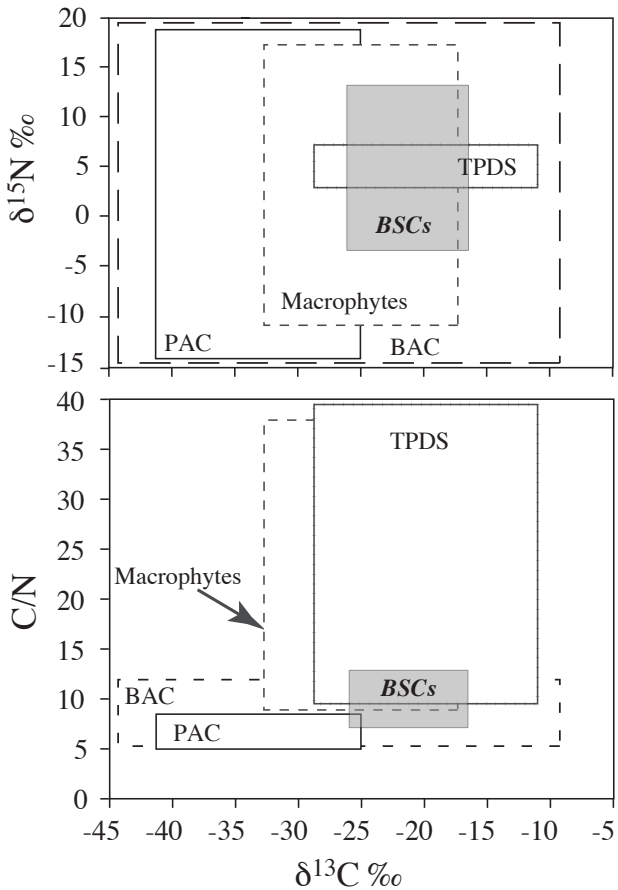




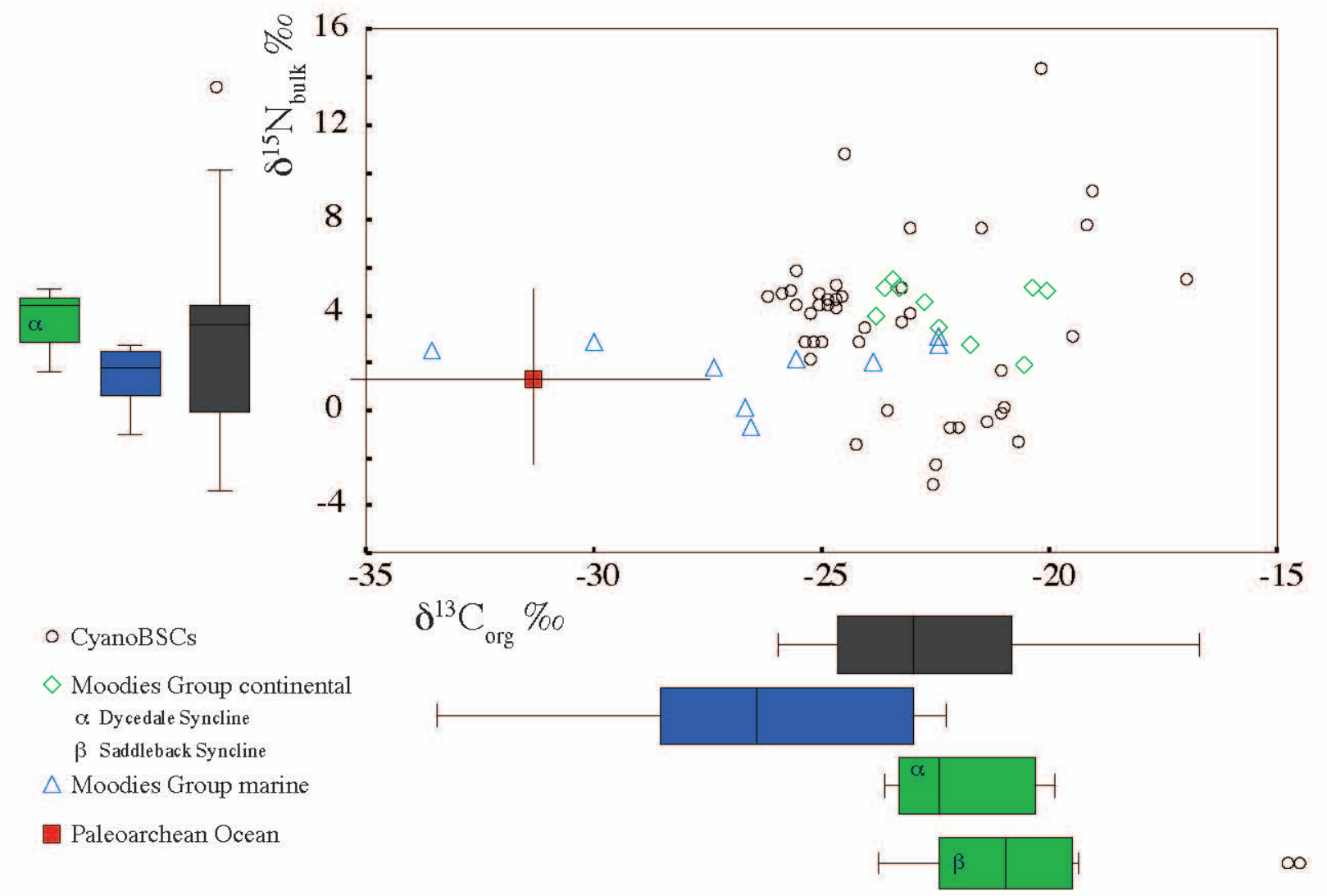



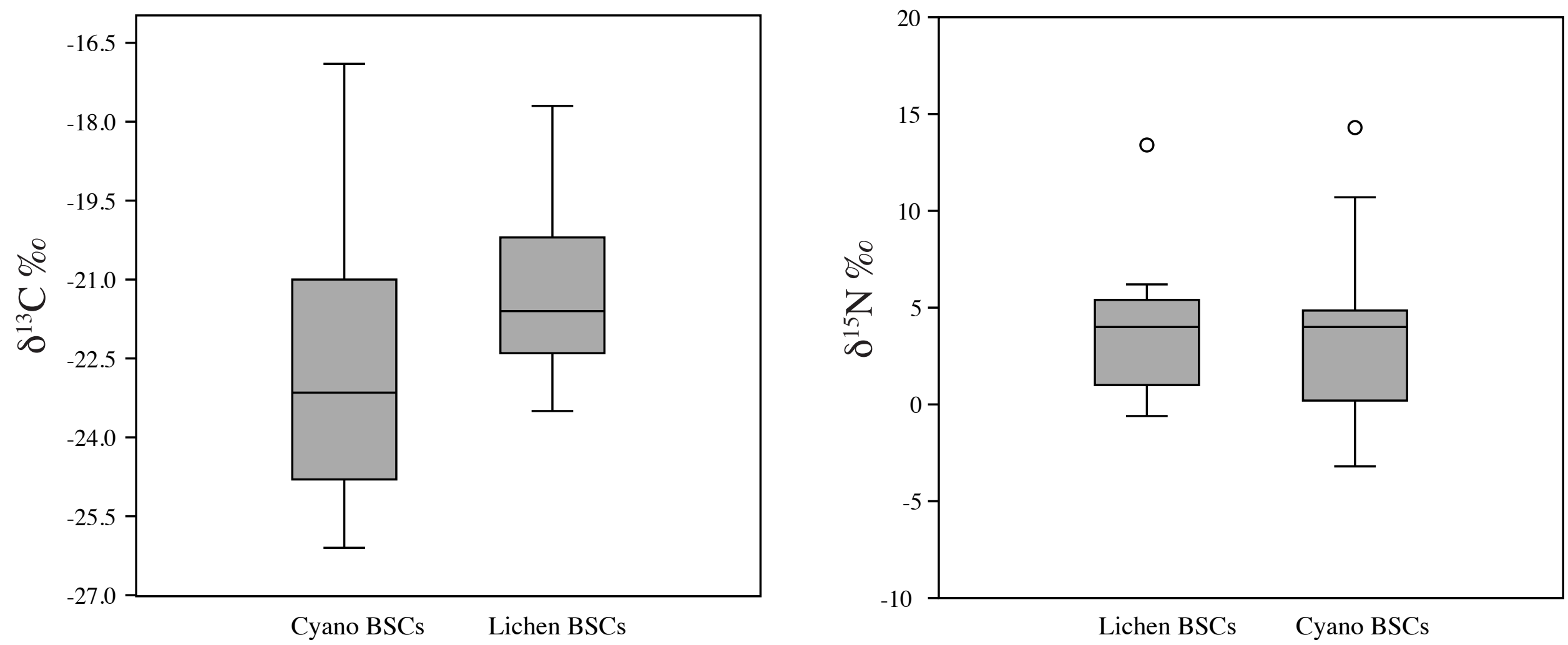

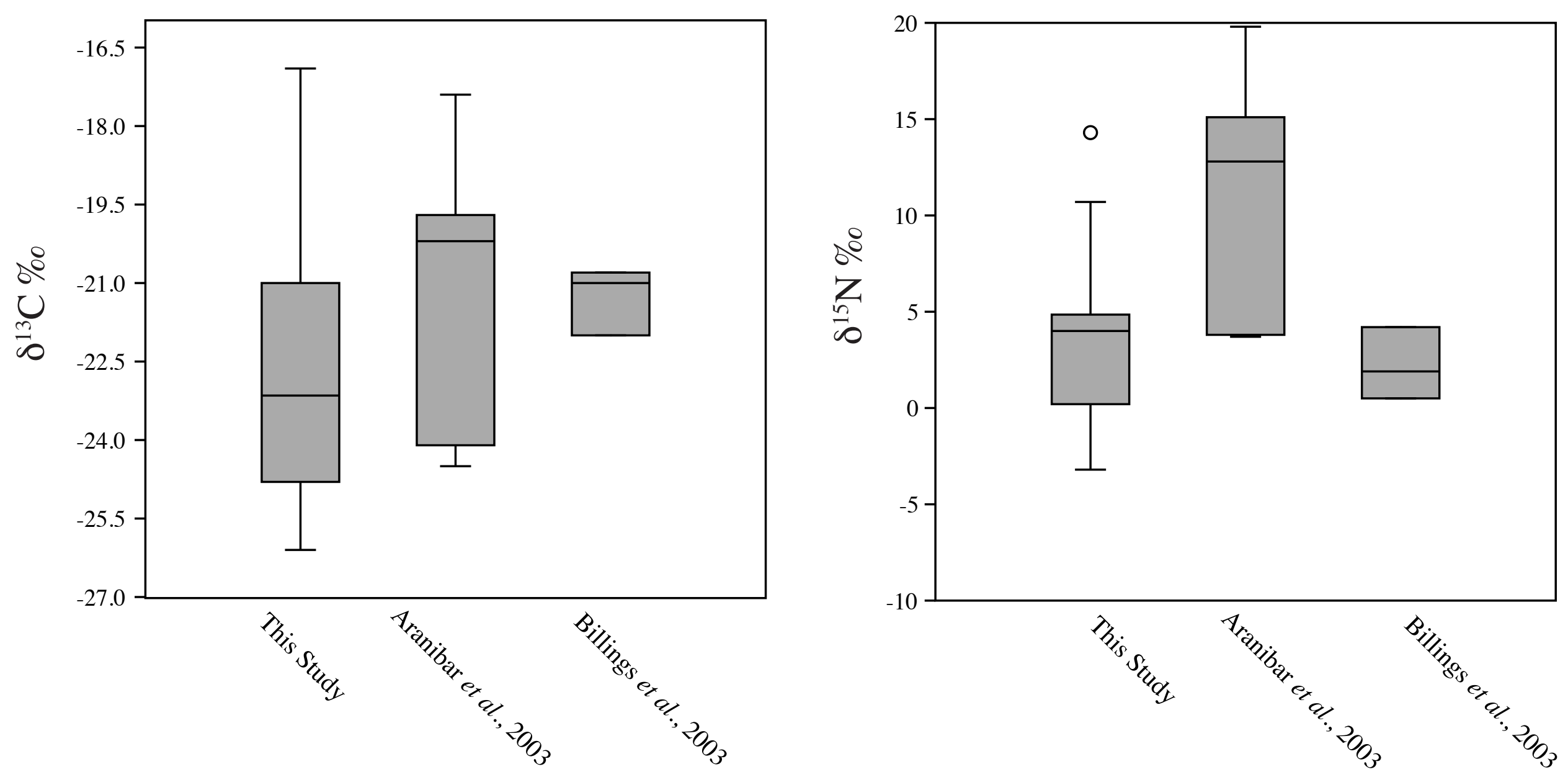


\begin{tabular}{|c|c|c|c|c|c|c|c|}
\hline \multirow[t]{2}{*}{ Sample ID } & \multirow[t]{2}{*}{$\begin{array}{l}\text { Successional } \\
\text { stage }\end{array}$} & \multirow[t]{2}{*}{ Location } & \multicolumn{2}{|l|}{ GPS coordinates } & \multirow[t]{2}{*}{$\begin{array}{r}\delta^{13} \mathrm{C}(\%) \\
\text { Vs PDB }\end{array}$} & \multirow[t]{2}{*}{$\begin{array}{r}\delta^{15} \mathrm{~N}(\%) \\
\text { Vs AIR }\end{array}$} & \multirow[t]{2}{*}{$\begin{array}{r}\mathrm{C} / \mathrm{N} \text { atomic } \\
\text { ratio }\end{array}$} \\
\hline & & & Lat & Long & & & \\
\hline 3FBCYA & Early & $\begin{array}{l}\text { Chihuahuan Desert - } \\
\text { Fort Bliss air force }\end{array}$ & $32^{\circ} 25^{\prime} 51.85^{\prime \prime} \mathrm{N}$ & $105^{\circ} 59^{\prime} 2.94 " \mathrm{~W}$ & -19.8 & N.D. & N.D. \\
\hline $5 \mathrm{~GB}$ & Early & Moab, UT & $38^{\circ} 42^{\prime} 57.7 " \mathrm{~N}$ & $109^{\circ} 41^{\prime} 31.1^{\prime \prime W}$ & -19.3 & N.D. & N.D. \\
\hline 6GB1097 & Early & Moab, UT & $38^{\circ} 42^{\prime} 57.7^{\prime \prime} \mathrm{N}$ & $109^{\circ} 41^{\prime} 31.1^{\prime \prime} \mathrm{W}$ & -18 & N.D. & N.D. \\
\hline 19Arches & Early & $\begin{array}{l}\text { Arches National Park, } \\
\text { UT }\end{array}$ & $38^{\circ} 43^{\prime} 30.61 " \mathrm{~N}$ & $109^{\circ} 36^{\prime} 33.39^{\prime \prime W}$ & -23 & 0.4 & 10 \\
\hline 20UT & Early & Moab, UT & $38^{\circ} 34^{\prime} 58.7^{\prime \prime N}$ & $109^{\circ} 31^{\prime} 27.2^{\prime \prime W}$ & -22 & N.D. & N.D. \\
\hline 21DM & Early & Moab, UT & $38^{\circ} 34^{\prime} 58.7 " \mathrm{~N}$ & $109^{\circ} 31^{\prime} 27.2^{\prime \prime W}$ & -23.1 & N.D. & N.D. \\
\hline 23Green & Early & Moab, UT & $38^{\circ} 42^{\prime} 57.7 " \mathrm{~N}$ & $109^{\circ} 41^{\prime} 31.1^{\prime \prime W}$ & -18.7 & N.D. & N.D. \\
\hline $26 \mathrm{MO}$ & Early & Mojave desert, Arizona & $35^{\circ} 15^{\prime} 11.4^{\prime \prime N}$ & $115^{\circ} 58^{\prime} 38^{\prime \prime} \mathrm{W}$ & -20.5 & N.D. & N.D. \\
\hline 31 & Early & $\begin{array}{l}\text { Chihuahuan Desert - } \\
\text { Fort Bliss air force }\end{array}$ & $32^{\circ} 25^{\prime} 51.85^{\prime \prime} \mathrm{N}$ & $105^{\circ} 59^{\prime} 2.94 " \mathrm{~W}$ & -23.2 & 5 & 9.8 \\
\hline UNK & Early & Great Basin Desert, UT & $41^{\circ} 6^{\prime} 15.16 " \mathrm{~N}$ & $113^{\circ} 0^{\prime} 29.53^{\prime \prime} \mathrm{W}$ & -19.1 & 7.7 & 9.3 \\
\hline 35 & Early & $\begin{array}{l}\text { Desert Botanical } \\
\text { Garden, Phoenix }\end{array}$ & $33^{\circ} 27^{\prime} 49.29^{\prime \prime} \mathrm{N}$ & $111^{\circ} 56^{\prime} 40.75^{\prime \prime W}$ & -24.8 & 4.3 & 9.3 \\
\hline 36 & Early & $\begin{array}{l}\text { Desert Botanical } \\
\text { Garden, Phoenix }\end{array}$ & $33^{\circ} 27^{\prime} 49.29^{\prime \prime} \mathrm{N}$ & $111^{\circ} 56^{\prime} 40.75^{\prime \prime W}$ & -25.1 & 2.7 & 9.5 \\
\hline 37 & Early & $\begin{array}{l}\text { Desert Botanical } \\
\text { Garden, Phoenix }\end{array}$ & $33^{\circ} 27^{\prime} 49.29^{\prime \prime} \mathrm{N}$ & $111^{\circ} 56^{\prime} 40.75^{\prime \prime W}$ & -24.5 & 4.7 & 9.1 \\
\hline 38 & Early & $\begin{array}{l}\text { Desert Botanical } \\
\text { Garden, Phoenix }\end{array}$ & $33^{\circ} 27^{\prime} 49.29^{\prime \prime} \mathrm{N}$ & $111^{\circ} 56^{\prime} 40.75^{\prime \prime} \mathrm{W}$ & -25.2 & 2 & 9.9 \\
\hline 39 & Early & $\begin{array}{l}\text { Desert Botanical } \\
\text { Garden, Phoenix }\end{array}$ & $33^{\circ} 27^{\prime} 49.29^{\prime \prime} \mathrm{N}$ & $111^{\circ} 56^{\prime} 40.75^{\prime \prime W}$ & -25 & 4.3 & 10.1 \\
\hline
\end{tabular}




\begin{tabular}{|c|c|c|c|c|c|c|c|}
\hline 40 & Early & $\begin{array}{l}\text { Desert Botanical } \\
\text { Garden, Phoenix }\end{array}$ & $33^{\circ} 27^{\prime} 49.29^{\prime \prime} \mathrm{N}$ & $111^{\circ} 56^{\prime} 40.75^{\prime \prime W}$ & -24.9 & 2.8 & 10.1 \\
\hline 41 & Early & $\begin{array}{l}\text { Desert Botanical } \\
\text { Garden, Phoenix }\end{array}$ & $33^{\circ} 27^{\prime} 49.29 " \mathrm{~N}$ & $111^{\circ} 56^{\prime} 40.75^{\prime \prime W}$ & -25.3 & 2.7 & 11.0 \\
\hline 42 & Early & $\begin{array}{l}\text { Desert Botanical } \\
\text { Garden, Phoenix }\end{array}$ & $33^{\circ} 27^{\prime} 49.29^{\prime \prime} \mathrm{N}$ & $111^{\circ} 56^{\prime} 40.75^{\prime \prime W}$ & -24.8 & 4.6 & 8.6 \\
\hline DBG2 & Early & $\begin{array}{l}\text { Desert Botanical } \\
\text { Garden, Phoenix }\end{array}$ & $33^{\circ} 27^{\prime} 47.41^{\prime \prime} \mathrm{N}$ & $111^{\circ} 56^{\prime} 47.43^{\prime \prime W}$ & -24.6 & 5.2 & 11.6 \\
\hline XBU & Early & Xiaobing hill, UT & $38^{\circ} 42^{\prime} 58.7^{\prime \prime} \mathrm{N}$ & $109^{\circ} 41^{\prime} 33.7^{\prime \prime W}$ & -20.1 & 14.3 & 9.0 \\
\hline GREEN & Early & $\begin{array}{l}\text { Dinosaure Mountain, } \\
\text { Moab, UT }\end{array}$ & $38^{\circ} 42^{\prime} 58.7^{\prime \prime N}$ & $109^{\circ} 41^{\prime} 33.7^{\prime \prime W}$ & -21 & 1.5 & 10.1 \\
\hline DINO & Early & $\begin{array}{l}\text { Dinosaure Mountain, } \\
\text { Moab, UT }\end{array}$ & $38^{\circ} 42^{\prime} 58.7 " \mathrm{~N}$ & $109^{\circ} 41^{\prime} 33.7^{\prime \prime} \mathrm{W}$ & -23.2 & 3.6 & 7.1 \\
\hline CASA & Early & Casa Grande, Arizona & $32^{\circ} 59^{\prime} 28.9^{\prime \prime} \mathrm{N}$ & $111^{\circ} 45^{\prime} 40.6^{\prime \prime} \mathrm{W}$ & -23 & 7.5 & 6.9 \\
\hline Moabs1L & Early & Moab, UT & $38^{\circ} 42^{\prime} 58.7 " \mathrm{~N}$ & $109^{\circ} 41^{\prime} 33.7^{\prime \prime} \mathrm{W}$ & -20.6 & -1.4 & 8.1 \\
\hline SUN & Middle & $\begin{array}{l}\text { Sunday Churt, UT } \\
\text { Peralta trail, }\end{array}$ & $38^{\circ} 38^{\prime} \mathrm{N}$ & $109^{\circ} 39^{\prime} \mathrm{W}$ & -21.9 & -0.9 & 10.2 \\
\hline 17SM & Middle & $\begin{array}{l}\text { Supertition mountains, } \\
\text { Phoenix }\end{array}$ & $33^{\circ} 14^{\prime} 18.89^{\prime \prime} \mathrm{N}$ & $111^{\circ} 12^{\prime} 31.43^{\prime \prime W}$ & -23.5 & -0.1 & 9.7 \\
\hline 18Moab & Middle & Moab, UT & $38^{\circ} 42^{\prime} 58.7^{\prime \prime N}$ & $109^{\circ} 31^{\prime} 27.2^{\prime \prime} \mathrm{W}$ & -24.2 & -1.6 & 11.0 \\
\hline 22Cactus & Middle & Mojave desert, Arizona & $34^{\circ} 07^{\prime} 49.6^{\prime \prime} \mathrm{N}$ & $114^{\circ} 14^{\prime} 28.5^{\prime \prime} \mathrm{W}$ & -20.9 & 0 & 9.2 \\
\hline 25Chandler & Middle & Chandler, Arizona & $33^{\circ} 15^{\prime} 21.8^{\prime \prime} \mathrm{N}$ & $111^{\circ} 56^{\prime} 29.5^{\prime \prime} \mathrm{W}$ & -24.4 & 10.7 & 8.4 \\
\hline 32 & Middle & Great Basin Desert, UT & $41^{\circ} 6^{\prime} 15.16^{\prime \prime} \mathrm{N}$ & $113^{\circ} 1^{\prime} 23.49^{\prime \prime} \mathrm{W}$ & -23 & 4 & 10.9 \\
\hline 33 & Middle & Moab, UT & $38^{\circ} 38^{\prime} 6.36^{\prime \prime} \mathrm{N}$ & $109^{\circ} 38^{\prime} 9.19^{\prime \prime} \mathrm{W}$ & -21.3 & -0.6 & 10.8 \\
\hline 43 & Middle & $\begin{array}{l}\text { Desert Botanical } \\
\text { Garden, Phoenix }\end{array}$ & $33^{\circ} 27^{\prime} 49.29^{\prime \prime} \mathrm{N}$ & $111^{\circ} 56^{\prime} 40.75^{\prime \prime} \mathrm{W}$ & -25.2 & 4 & 10.9 \\
\hline
\end{tabular}




\begin{tabular}{|c|c|c|c|c|c|c|c|}
\hline 44 & Middle & $\begin{array}{l}\text { Desert Botanical } \\
\text { Garden, Phoenix }\end{array}$ & $33^{\circ} 27^{\prime} 49.29^{\prime \prime} \mathrm{N}$ & $111^{\circ} 56^{\prime} 40.75^{\prime \prime W}$ & -24.6 & 4.2 & 11.2 \\
\hline 45 & Middle & $\begin{array}{l}\text { Desert Botanical } \\
\text { Garden, Phoenix }\end{array}$ & $33^{\circ} 27^{\prime} 49.29^{\prime \prime} \mathrm{N}$ & $111^{\circ} 56^{\prime} 40.75^{\prime \prime W}$ & -25.5 & 5.7 & 10.3 \\
\hline 46 & Middle & $\begin{array}{l}\text { Desert Botanical } \\
\text { Garden, Phoenix }\end{array}$ & $33^{\circ} 27^{\prime} 49.29^{\prime \prime} \mathrm{N}$ & $111^{\circ} 56^{\prime} 40.75^{\prime \prime} \mathrm{W}$ & -25.5 & 4.3 & 11.7 \\
\hline 47 & Middle & $\begin{array}{l}\text { Desert Botanical } \\
\text { Garden, Phoenix }\end{array}$ & $33^{\circ} 27^{\prime} 49.29^{\prime \prime} \mathrm{N}$ & $111^{\circ} 56^{\prime} 40.75^{\prime \prime W}$ & -25.6 & 4.9 & 10.8 \\
\hline 48 & Middle & $\begin{array}{l}\text { Desert Botanical } \\
\text { Garden, Phoenix }\end{array}$ & $33^{\circ} 27^{\prime} 49.29^{\prime \prime} \mathrm{N}$ & $111^{\circ} 56^{\prime} 40.75^{\prime \prime W}$ & -24.6 & 4.6 & 11.7 \\
\hline 49 & Middle & $\begin{array}{l}\text { Desert Botanical } \\
\text { Garden, Phoenix }\end{array}$ & $33^{\circ} 27^{\prime} 49.29^{\prime \prime} \mathrm{N}$ & $111^{\circ} 56^{\prime} 40.75^{\prime \prime} \mathrm{W}$ & -25 & 4.8 & 10.9 \\
\hline 50 & Middle & $\begin{array}{l}\text { Desert Botanical } \\
\text { Garden, Phoenix }\end{array}$ & $33^{\circ} 27^{\prime} 49.29^{\prime \prime} \mathrm{N}$ & $111^{\circ} 56^{\prime} 40.75^{\prime \prime} \mathrm{W}$ & -26.1 & 4.7 & 12.1 \\
\hline DBG1 & Middle & $\begin{array}{l}\text { Desert Botanical } \\
\text { Garden, Phoenix }\end{array}$ & $33^{\circ} 27^{\prime} 47.41^{\prime \prime} \mathrm{N}$ & $111^{\circ} 56^{\prime} 47.43^{\prime \prime} \mathrm{W}$ & -24 & 3.3 & 9.1 \\
\hline DBG4 & Middle & $\begin{array}{l}\text { Desert Botanical } \\
\text { Garden, Phoenix }\end{array}$ & $33^{\circ} 27^{\prime} 47.41^{\prime \prime} \mathrm{N}$ & $111^{\circ} 56^{\prime} 47.43^{\prime \prime} \mathrm{W}$ & -24 & 3.3 & 10.3 \\
\hline DBG5 & Middle & $\begin{array}{l}\text { Desert Botanical } \\
\text { Garden, Phoenix }\end{array}$ & $33^{\circ} 27^{\prime} 47.41 " \mathrm{~N}$ & $111^{\circ} 56^{\prime} 47.43^{\prime \prime} \mathrm{W}$ & -25.8 & 4.8 & 12.4 \\
\hline DBG7 & Middle & $\begin{array}{l}\text { Desert Botanical } \\
\text { Garden, Phoenix }\end{array}$ & $33^{\circ} 27^{\prime} 47.41 " \mathrm{~N}$ & $111^{\circ} 56^{\prime} 47.43^{\prime \prime} \mathrm{W}$ & -24.1 & 2.8 & 7.1 \\
\hline Moabsd & Middle & Great Basin Desert, UT & $38^{\circ} 42^{\prime} 58.7^{\prime \prime} \mathrm{N}$ & $109^{\circ} 41^{\prime} 33.7^{\prime \prime} \mathrm{W}$ & -22.4 & -2.4 & 9.0 \\
\hline Moabs1dk & Middle & Great Basin Desert, UT & $38^{\circ} 42^{\prime} 58.7 " \mathrm{~N}$ & $109^{\circ} 41^{\prime} 33.7^{\prime \prime} \mathrm{W}$ & -22.5 & -3.2 & 9.4 \\
\hline 7GB1084 & Middle & Moab, UT & $38^{\circ} 39^{\prime} 22^{\prime \prime} \mathrm{N}$ & $109^{\circ} 39^{\prime} 14.4^{\prime \prime} \mathrm{W}$ & -21 & -0.3 & 11.0 \\
\hline 8GB1014 & Middle & Moab, UT & $38^{\circ} 39^{\prime} 22^{\prime \prime} \mathrm{N}$ & $109^{\circ} 39^{\prime} 14.4^{\prime \prime} \mathrm{W}$ & -21.9 & -0.9 & 11.7 \\
\hline
\end{tabular}




\begin{tabular}{|c|c|c|c|c|c|c|c|}
\hline 10FB2013 & Middle & $\begin{array}{l}\text { Chihuahuan Desert - } \\
\text { Fort Bliss air force }\end{array}$ & $32^{\circ} 25^{\prime} 51.85 " \mathrm{~N}$ & $105^{\circ} 59^{\prime} 2.94 " \mathrm{~W}$ & -19.4 & 3 & 9.5 \\
\hline 12HSI5 & Middle & Great Basin Desert, UT & $41^{\circ} 6^{\prime} 15.16^{\prime \prime} \mathrm{N}$ & $113^{\circ} 0^{\prime} 29.53^{\prime \prime W}$ & -19 & 9.1 & 9.3 \\
\hline 13HSA5 & Middle & $\begin{array}{l}\text { Great Basin Desert, UT } \\
\text { Peralta trail, }\end{array}$ & $41^{\circ} 6^{\prime} 15.16^{\prime \prime} \mathrm{N}$ & $113^{\circ} 0^{\prime} 29.53^{\prime \prime} \mathrm{W}$ & -16.9 & 5.4 & 9.3 \\
\hline 16PT & Middle & $\begin{array}{l}\text { Supertition mountains, } \\
\text { Phoenix }\end{array}$ & $33^{\circ} 14^{\prime} 18.89 " \mathrm{~N}$ & $111^{\circ} 12^{\prime} 31.43^{\prime \prime W}$ & -22.1 & -0.9 & 9.1 \\
\hline $27 \mathrm{CH}$ & Middle & Chandler, Arizona & $33^{\circ} 15^{\prime} 21.8^{\prime \prime} \mathrm{N}$ & $111^{\circ} 56^{\prime} 29.5^{\prime \prime W}$ & -21.4 & 7.6 & 9.5 \\
\hline $1 \mathrm{HSN}$ & $\begin{array}{l}\text { Middle- } \\
\text { Lichens }\end{array}$ & Great Basin Desert, UT & $41^{\circ} 6^{\prime} 15.2^{\prime \prime} \mathrm{N}$ & $113^{\circ} 1^{\prime} 23.50 " \mathrm{~W}$ & -18.3 & 6.2 & 10.3 \\
\hline $2 \mathrm{HS}$ & $\begin{array}{l}\text { Middle- } \\
\text { Lichens }\end{array}$ & Great Basin Desert, UT & $41^{\circ} 6^{\prime} 15.2^{\prime \prime} \mathrm{N}$ & $113^{\circ} 1^{\prime} 23.50^{\prime \prime W}$ & -21.9 & 4 & 9.1 \\
\hline 4HSBCYA & $\begin{array}{l}\text { Middle- } \\
\text { Lichens }\end{array}$ & Great Basin Desert, UT & $41^{\circ} 6^{\prime} 15.2^{\prime \prime} \mathrm{N}$ & $113^{\circ} 1^{\prime} 23.50^{\prime \prime W}$ & -21.6 & 5.4 & 9.9 \\
\hline 9NM17 & $\begin{array}{l}\text { Middle- } \\
\text { Lichens }\end{array}$ & $\begin{array}{l}\text { Cibola National Forest, } \\
\text { New Mexico }\end{array}$ & $35^{\circ} 12^{\prime} 13.33 " \mathrm{~N}$ & $106^{\circ} 28^{\prime} 22.98^{\prime \prime W}$ & -21.1 & 1 & 12.1 \\
\hline 11A2013 & $\begin{array}{l}\text { Middle- } \\
\text { Lichens }\end{array}$ & $\begin{array}{l}\text { A mountain, Las } \\
\text { Curces, New Mexico }\end{array}$ & $32^{\circ} 17^{\prime} 55.97 " \mathrm{~N}$ & $106^{\circ} 42^{\prime} 5.15^{\prime \prime W}$ & -21.4 & 5.3 & 9.5 \\
\hline 17Taylor & $\begin{array}{l}\text { Middle- } \\
\text { Lichens }\end{array}$ & $\begin{array}{l}\text { Jornada LTER, New } \\
\text { Mexico }\end{array}$ & $32^{\circ} 17^{\prime} 55.97 " \mathrm{~N}$ & $106^{\circ} 42^{\prime} 5.15^{\prime \prime W}$ & -18.5 & 2.1 & 9.1 \\
\hline 15CG & $\begin{array}{l}\text { Middle- } \\
\text { Lichens } \\
\text { Middle- }\end{array}$ & Casa Grande, Arizona & $32^{\circ} 59^{\prime} 28.9^{\prime \prime} \mathrm{N}$ & $111^{\circ} 45^{\prime} 40.6^{\prime \prime} \mathrm{W}$ & -22.9 & 4.1 & 6.9 \\
\hline 24San & $\begin{array}{l}\text { Middle- } \\
\text { Lichens }\end{array}$ & Sonoran, Arizona & $32^{\circ} 45^{\prime} 2.3^{\prime \prime} \mathrm{N}$ & $113^{\circ} 39^{\prime} 19.0^{\prime \prime} \mathrm{W}$ & -17.7 & 13.4 & 10.0 \\
\hline 29 & $\begin{array}{l}\text { Middle- } \\
\text { Lichens } \\
\text { Middle- }\end{array}$ & $\begin{array}{l}\text { A mountain, Las } \\
\text { Curces, New Mexico }\end{array}$ & $32^{\circ} 17^{\prime} 55.97 " \mathrm{~N}$ & $106^{\circ} 42^{\prime} 5.15^{\prime \prime W}$ & -22.6 & 2.8 & 9.4 \\
\hline $30 X 1$ & Lichens & Great Basin Desert, UT & $41^{\circ} 6^{\prime} 15.16^{\prime \prime} \mathrm{N}$ & $113^{\circ} 0^{\prime} 29.53^{\prime \prime W}$ & -22.3 & 5.3 & 9.5 \\
\hline
\end{tabular}




\begin{tabular}{|c|c|c|c|c|c|c|c|}
\hline DBG3 & $\begin{array}{l}\text { Middle- } \\
\text { Lichens }\end{array}$ & $\begin{array}{l}\text { Desert Botanical } \\
\text { Garden, Phoenix }\end{array}$ & $33^{\circ} 27^{\prime} 47.41^{\prime \prime} \mathrm{N}$ & $111^{\circ} 56^{\prime} 47.43^{\prime \prime W}$ & -23.5 & 0.8 & 9.4 \\
\hline XBC & $\begin{array}{l}\text { Middle- } \\
\text { Lichens } \\
\text { Middle- }\end{array}$ & $\begin{array}{l}\text { Xiaobing chihuahua, } \\
\text { New Mexico }\end{array}$ & $32^{\circ} 32^{\prime} 60^{\prime \prime} \mathrm{N}$ & $106^{\circ} 43^{\prime} 12^{\prime \prime W}$ & -20.9 & 0.6 & 9.4 \\
\hline XBH & Lichens & Xiaobing hill, UT & $41^{\circ} 6^{\prime} 0 " \mathrm{~N}$ & $113^{\circ} 0^{\prime} 0^{\prime \prime} \mathrm{W}$ & -22.4 & 5.6 & 9.7 \\
\hline CIBOLE & $\begin{array}{l}\text { Middle- } \\
\text { Lichens }\end{array}$ & $\begin{array}{l}\text { Cibola National Forest, } \\
\text { New Mexico }\end{array}$ & $34^{\circ} 12^{\prime} 25.9^{\prime \prime} \mathrm{N}$ & $107^{\circ} 55^{\prime} 22.1 " \mathrm{~W}$ & -20.2 & 1.1 & 11.4 \\
\hline Moab-S3 & $\begin{array}{l}\text { Michale- } \\
\text { Lichens }\end{array}$ & Great Basin Desert, UT & $38^{\circ} 42^{\prime} 58.7^{\prime \prime N}$ & $109^{\circ} 41^{\prime} 33.7 " \mathrm{~W}$ & -22.3 & -0.6 & 10.3 \\
\hline
\end{tabular}

*N.D. non-determined - below detection limit 